Research Article

\title{
The Principal's Leadership Style in Empowering Educators in Schools
}

\author{
Hendro Nur Wibowo *, Muhammad Saleh, Rustam Effendi \\ Master Program of Education Management. Universitas Lambung Mangkurat, Banjarmasin 70123, \\ Indonesia
}

Article history:

Submission November 2019

Revised June 2020

Accepted July 2020

*Corresponding author:

E-mail: pakhendronw@gmail.com

\begin{abstract}
The purpose of this study is to describe the leadership style of the Principal of Banjarmasin 5 Vocational High School in empowering educators. This is descriptive research. The data collection techniques were triangulation and included interviews, observation, and documentation. The results of this research showed applied leadership style is participative, as evidenced by the involvement of all school members in key aspects such as the school program, joint decision, personal selection and delegation of authority, information disclosure, and communication. The results of this research might be used as a basis for applying leadership styles in other schools.
\end{abstract}

\section{Introduction}

In the last few years, the government has held several school quality management programs. A good example in this regard includes school-based quality improvement or management. This government program requires the carrying capacity of all school components to have a high level of competence. In general, competent educators are essential in carrying out several programs. A school with adequate infrastructure, sufficient funds, and enough resources are perceived to be in vain in case it is not supported by educators and education staff who have the competence and professionalism to carry out all the tasks proportionally. Therefore, for s school to be superior, proper management from the principal is needed, for it is optimized and supported by educators and education staff in the school (Mulyasa, 2009)

A superior school is a school with a high level of effectiveness, in achieving the vision, mission and objectives are realized ineffective school activities with the high carrying capacity of all school components, One of the carrying capacity is shown from the work performance of school principals who can manage their human resources and the work performance of all educators and educational staff who work professionally (Aedi, 2016).

The leadership style of a principal greatly influences the quality of education. The principal influence and motivate teachers to achieve a school's vision and positively influence professionalism and learning outcomes (Matondang, 2008). A leader applies a certain style of leadership. Application of leadership style in the form of task behavior patterns and tolerance behavior patterns (Yoto, 2011).

One of the important competencies that must be owned by a leader is the ability to be able to motivate his subordinates. The principal acts as a motivator for both the subordinates and the surrounding environment. Leadership has a very large influence on improving employee performance because of the role model leaders and the spotlight from subordinates. Thus if an organization wants to have high performance, leadership is needed that can move the subordinates so that they feel motivated to do

How to cite:

Wibowo, H. N., Saleh, M., \& Effendi, R. (2020). The principal's leadership style in empowering educators in schools. Journal of K6, Education, and Management, 3 (1), 1 - 7. doi: 10.11594/jk6em.03.01.01 
work with high performance (Suriansyah \& Aslamiah , 2012).

Principal leadership is an important factor in improving the discipline of teachers, principals as school leaders have an important role to mobilize, guide, protect, foster, set an example, encourage, and help teachers, students and staff in schools, roles, and functions the most important thing for school principals is to move all the resources available in a school. So that it can be utilized maximally to achieve the stated goals (Suriansyah \& Aslamiah, 2012).

The characteristics of an effective leader are very influential on his subordinates, including : (1) develop, train and protect; (2) communicate effectively with subordinates; (3) provide information to subordinates about what is expected; (4) set high standards of work; (5) regarding subordinates and their abilities; (6) giving roles to subordinates in the decision making process; (7) provide information about the condition of the organization; (8) be aware of the moral condition of the organization and always improve it; (9) willing to make changes; dan (10) appreciate the achievements of subordinates (Tim Dosen Administrasi Publik, 2011).

The principal's leadership style is the attitude, gestures that the principal makes to influence his subordinates. An effective leadership style is needed to improve and develop the quality of education in schools. A leadership style approach to behavior is a comprehensive pattern of the actions of a leader, both visible and invisible to subordinates (Nurkolis, 2002).

Characteristics of effective leadership styles affect the behavior of subordinates according to Lazaruth (1992) is otoriter, laissez-faire, and democratic. The choice of leadership style requires a leader who has effective criteria so that in making decisions there is no misunderstanding and can be following planned objectives. Considering the important role of the principal in leading the school, the principal must be able to work well together so that the quality of education in the school will be optimal.
It can be concluded that whatever the principal's leadership style, but the most important thing is that the principal can support the performance and appreciate his subordinates.

One of the schools in the Banjarmasin area was considered to have a large number of students as well as teaching staff. Besides, it has high achievements for vocational schools, therefore researchers are interested in knowing the principal's leadership style in empowering educators since it can offer 15 majors competency expertise.

In general, the purpose of this study is to describe the principal's leadership style in empowering teaching staff in schools. Specifically, this research aims to determine the school's leadership style.

\section{Material and Methods}

This is a descriptive study using a qualitative approach. The location of research was Banjarmasin 5 Vocational High School located on Soetoyo street No. 330 Banjarmasin, Banjarmasin City, South Kalimantan Province. A sampling of data is based on purposive or snowball, while data collection techniques use a triangulation approach, including, interviews, observation, and questionnaires. Data analysis is inductive/ qualitative and the results of qualitative research emphasize the meaning of generalization.

Research subjects were the principal, viceprincipal, teacher, and head of the expertise program. The validity of the data is obtained by extending the participation and triangulation of the data. Data analysis is carried out in three ways, including (a) data reduction, (b) data presentation, (c) conclusion / verification presentation.

\section{Results and Discussion}

Findings regarding the principal in planning school teacher development activities especially in planning. The Leadership Style in Empowering Educators in School Program Planning is evident from several aspects, including how the principal (1) engages Educators in school program planning, (2) coordinates the teaching staff in school 
program planning activities, (3) encourages educators in the evaluation or supervision team on the school program and (4) follows up on the results of the teacher's evaluation on the school program. Which stated that Suriansyah and Aslamiah (2015) as an education leader, a school principal should be able to organize the school and the personnel into situations that are efficient, democratic, and institutional cooperation.

The next finding regarding empowering educators in the school program begins with holding a meeting with key stakeholders for discussing the school program to be implemented. In every decision-making process in empowering educators, the Principal always involves the deputy of Workforce, since the duties and responsibilities require coordination of working groups and homeroom teachers and their job descriptions. Also, it involves inventorying and making a map of the potential competencies of expertise, teaching, and administrative staff. Therefore, in the determination of officers in each program, the principal only makes approvals. The principal's leadership style involving all school members in socializing and running this school program is participative.

The results of the study are in line with Somech (2010) in Haifa that by applying Participative Decision Making (PDM) allows identifying the conditions under which such effectiveness of it processes and outcomes should ultimately render guidelines that can be directly incorporated into school practice.

According to Rusdinal (2016), a participative leadership style is illustrated in delegating some authority to subordinates. Not all decisions depend only on the Principal, subordinates have the authority to decide according to the duties and responsibilities of each office in the school, but it is still within reasonable limits in with applicable procedures. According to Degeng \& Sutarto (2015), the participatory leadership style involves exchanging ideas in decision making, with the primary role of leaders providing facilities and communicating. This style involves high work relationship behavior and a low task-oriented approach. In this leadership style, a follower makes it possible to express ideas and have the opportunity to realize their role in the group, as well as the ability to be empowered by the leader at any time for the progress of the group and organization being followed.

Communication between the Principal and subordinates is effective. Without fear due to position, supervision is carried out appropriately by the Principal through subordinates who have been assigned. As a result, there is no pressure on subordinates when carrying out their activities, subordinates also uphold the trust given by their superiors are participatory leadership styles.

Several school programs have been carried out to improve the quality of education, including the development of students and alumni potentials, the development of educational programs on expertise competencies, English language advancement and empowerment programs for teachers and students, the School production unit development program leads to the Teaching Factory, Spiritual guidance work program and Islamization (ROHIS), arts and music development, sports development, student cooperative, and educational programs for normative and adaptive education. All the officers who take care of all these school programs are all teaching staff with the name listed on the Decree of the Head of the Decree to carry out the school program. The name of the proposed officer for each program comes from the Vice Principal of Workforce. From every school program implemented, there is an audit team that oversees and evaluates each existing program, and that is the Vice Principal of Quality Management. The Principal entrusts an audit for each school program to them because his duties and responsibilities include (1) Coordinating the implementation of Internal Audit, (2) Conducting a review of the Internal Audit System, (3) Coordinating the implementation of External Audit, and (4) ) Coordinating the implementation of the Management Review Meeting. The Principal along with the teaching staff compiles a description of the tasks and responsibilities of the organization's management, arranged appropriately. The duties of each administrator 
cannot be interrupted in the organization. In this division of tasks, it is also very efficient and effective because in every school program there is always a person in charge of the activities carried out by the Vice-Principal and the highest person in charge by the Principal. As a result, the main objectives of the organization through the school program might be achieved for common goals and interests.

The principal's way of giving assignments to educators is based on the job description made. The Principal encourages members to carry out tasks by giving opportunities to subordinates, allowing them to participate in decision making. This creates a friendly atmosphere and relationships of mutual trust and respect with group members.

Principals emphasize the high level of support from subordinates in decision making and policy. However, there is little direction for asking and using subordinate's advice in decision making. Principals and subordinates exchange ideas in problem-solving and decision making. In discharging their duties the Principal is willing to accept and even expect opinions and suggestions from his subordinates, as well as constructive criticism from educators and personnel as feedback (suhaimi \& Abdul, 2018).

The Leadership Style might be evident in several aspects, including how the principal (1) the arranges the teaching staff in organizing, (2) performs the division of positions or tasks of teaching staff in organizing, and (3) empowers officers to implement the tasks and functions of the school organization This is in line with Suriansyah and Aslamiah (2015) the Leadership Strategies of School Principals, Parents, and Communicative in the building the Students Characters.

The duties and functions of the Vice Principal of Workforce include coordinating with the Principal to arrange management staff personnel, working groups, and homeroom teachers along with their job descriptions, as stated in the Principal's Decree and inventory. The Principal also gives the responsibility to propose the name of the educator in running the organization. The name of the educator is analyzed directly by monitoring of each educator, teacher competency, and diploma qualifications. Empowering educators in the organizational structure of each position still involve coordinating with the Vice Principal of Labor. This is because it is a duty to empower educators in every activity in the school. As a result, the Principal gives authority to the Vice Principal of the Workforce following his duties and responsibilities. The Principal assigns the teaching staff not based only on instructions, but also on an analysis that has been carried out.

To realize empowerment in an organization, a leader needs to understand three main basic beliefs, including (1) Subsidiarity. This principle teaches that members of higher rank cannot take responsibility. There is a need to confer responsibilities to lower members. In other words, taking people's responsibilities is a mistake, because this situation ultimately makes the person unskilled. (2) The staff is kind. The essence of staff empowerment is based on the assertion that beliefs about people are good. To be able to empower others, superiors need to believe that "for all time, almost everyone uses their power to realize their vision and be guided by the virtues." Staff empowerment is attained, in case there is no longer supervision, checking, verification, and regulating the activities of people who work in the organization. Leaders empower by providing adequate training and technology for staff, giving the right direction, and enabling staff to do everything possible. (3) Trust-based relationship. Staff empowerment emphasizes aspects of trust by management to staff. The relationship between management and staff is trust-based. In general, trust is built by staff through their performance.

Another opinion regarding the role of the principal in the empowerment of teachers by the form of assignment of teachers in teaching which is the principal's strategy that prioritizes each teacher so that it can be implemented well by each teacher (Susanto, 2016). Research findings regarding the ability to apply participatory leadership styles through organizing educational staff in implementing 
programs that are: (1) the Principal asks for ideas and opinions from subordinates regarding human resources to carry out school programs and seriously considers their suggestions and concerns. (2) Decisions are made together. The Principal coordinates with the Vice Staff to discuss the problems encountered and make joint decisions. (3) The Principal delegates the human resources by giving authority or responsibility to make decisions to a person or group. The Principal usually determines the final decision-making limit before it is applied to the School Decree (SD) of the Head of School.

This is consistent with some expert opinions regarding participative leadership styles. In general, the style involves the efforts of leaders to encourage and facilitate the participation of subordinates in making decisions on their behalf. It requires a leader to involve subordinates in decision making (Yulk \& gary, 2011). Aspects of a participatory leadership style include consultation, joint decision making, power-sharing, decentralization, and democratic management. The direct indicator of participatory leadership lies in follower behavior based on employee perceptions of the leadership style used (Riyono \& Zulaifah, 2001).

Being a participative leader means involving all team members in decision making. This is very important in case creative thinking is needed to solve complex problems or make decisions and have an impact on team members. Subordinates are encouraged to think about the relevance of existing ways, value systems, beliefs, expectations, and organizational forms. There is a need for them to be innovative in solving problems, create self-improvement, and set challenging goals or targets. This means subordinates are allowed to express and develop themselves through the tasks they face.

Based on the findings that the efforts of principals in improving the quality of education, efforts are needed to optimize all components, implementers, and educational activities. The Principal play a significant role in developing the quality of education in schools. The development of enthusiasm for work, harmonious cooperation, interest in education, a conducive and pleasant work atmosphere, and professional quality is largely determined by the quality of the Principal's leadership.

This is in line with the results of research conducted that the principal through his leadership style is empowering the potential of the teacher in the learning process, agenda in completing tasks, fair, effective, efficient, responsible and accountable and work through a management team that involves all school components.

Other studies conducted with Marks and Printy (2003) di United States, that transformational leadership by the principal is essential in supporting the commitment of teachers because teachers themselves can be barriers to the development of teacher leadership. When the principal elicits high levels of commitment and professionalism from teachers and works interactively with teachers in a shared instructional capacity.

The next finding is concerning the principal guide, assist and direct the teaching staff to appreciate and carry out school programs. The principal carries out various supervision and control of the school program through the Vice Principal of Quality Management and Whatsapp application to motivate educators and prevent the teaching staff from making deviations and be more careful in their duties.

According to the results of research Saputri \& Karwanto (2012) that the principal coordinates the school community through the WhatsApp group and provides advice and criticism of the teacher through meetings and WhatsApp application group. The efforts of other principals in applying their leadership style within to increase the insight of the professionalism from educators, the Principal provides professional development by assigning teachers who take part in training, seminars, workshops, and increasing the qualifications of diplomas from educators. According to the opinion Danim (2007) that an institution involves 4 (four) dominant factors, are: (1) the principal's leadership must have and understand the work vision, be able to work together, provide services and work discipline; (2) teachers in improving the competence of the teacher's professional 
profession in training activities and their application; (3) students with the approach taken are "student center" so that their competencies and abilities can be explored; and (4) curriculum that is consistent, dynamic and integrated.

It can be concluded that the principal's leadership style SMK Negeri 5 Banjarmasin in empowering educators to implement school programs leads and the Principal show leadership skills by: (1) participating in monitoring every program through discussion with the Vice Principal Quality management and the media online, (2) creating channels of information and communication at every opportunity through online to determine the problems that occur and find solutions together, (3) providing opportunities for various activities carried out outside of the school.

According to Blanchard et al. (2002) that Participatory is a leadership style that has characteristics of high relationships and low tasks where leaders and subordinates give each other ideas, leaders and subordinates together make decisions. This means that the participatory leadership style places more emphasis on high support in decision making and policy but with little direction. High leadership style in low support and direction is referred to as "participatory" because the position of control over problem-solving and decision making is held alternately.

\section{Conclusion and Recommendation}

The principal of the Banjarmasin Vocational School adopted a participatory leadership style in empowering educators. This is evident from the involvement of all school members in-school programs, where the Principal involves all teaching staff and all administrative staff in program planning to joint decision making in managing school programs, information disclosure, communication, consultation, and delegation of tasks to improve work professionalism.

This research offers information and references about leadership style. From this study, the participative leadership style is characterized by the willingness to open space and the participation of subordinates seriously in carrying out school programs. Also, school principals and subordinates exchange ideas in problem-solving and decision making that inspire and serve as an example in maintaining the activities carried out at school.

\section{Acknowledgment}

The author's thanks for all lectures at the Educational Management Study Program for facilitating the sustainability of this journal.

\section{References}

Aedi, N. (2016). Manajemen pendidik \& tenaga kependidikan. Yogyakarta: Gosyen Publisihing.

Blanchard, Hersey, P., \& Johnson, D. (2002). Management of organizational behavior utilizing human resources seventh edition. New Jersey: Prentice Hall.

Danim, S. (2007). Visi baru manajemen sekolah. Jakarta: Bumi Aksara.

Degeng, I. N., \& Sutarto, H. (2015). Menuju sekolah unggul dalam perspektif teori dan praktik. Prosiding Seminar Nasional FS2DMP Unlam ISSN: 2548-5598 Volume 1, Nomor 1,2015 (pp. 47-50). Banjarmasin: Program PG-PSD Universitas Lambung Mangkurat.

Lazaruth, S. (1992). Kepala sekolah dan tanggungjawabnya. Yogyakarta: Kanisius.

Marks, H. M., \& Printy, S. M. (2003). Principal leadership and school performance: An integration of transformational and instructional leadership. Journal of Educational Administration Quarterly, 39(3), 370-397. doi:10.1177/0013161X03253412.

Matondang. (2008). Kepemimpinan: Budaya Organisasi dan Manajemen Strategik. Yogyakarta: Graha Ilmu .

Mulyasa, E. (2009). Menjadi Kepala Sekolah Profesional. Bandung: PT. Remaja Rosdakarya.

Nurkolis. (2002). Manajemen berbasis sekolah. Jakarta: Grasindo. Riyono, E., \& Zulaifah, B. (2001). Psikologi kepemimpinan. Yogyakarta: Unit Publikasi Fakultas Psikologi UGM.

Rusdinal. (2016). Membangun pendidikan berkualitas berbasis karakter, strategi dan implementasinya. Prosiding Seminar Nasional PS2DMP Unlam (p. 23). Banjarmasin: Program PG-PSD Universitas Lambung Mangkurat.

Saputri, S. A., \& Karwanto. (2012). Kepemimpinan pembelajaran kepala sekolah dalam meningkatkan kinerja guru di SMP Negeri 1 Sidoarjo. Jurnal Inspirasi Manajemen Pendidikan, 1(1), 1-12. Retrieved from http://jurnalmahasiswa.unesa.ac.id/index.php/inspirasimanajemen-pendidikan/article/download/18002/16407 
Somech, A. (2010). Participative Decision Making in schools: A mediating-moderating analytical framework for understanding school and teacher outcomes. Journal of Educationa Administration Quarterly, 46(2), 175-209. doi:10.1177/1094670510361745.

Suhaimi, \& Abdul, K. (2018). Kepemimpinan transformasional kepala sekolah pada SMP Muhammadiyah 4 Banjarmasin. Jurnal Penelitian Tindakan dan Pendidikan 4(1)-2018, 4(1), 37-46. $\quad$ Retrieved from https://rumahjurnal.net/ptp/article/view/186/140

Suriansyah, A., \& Aslamiah. (2012). Menuju kepala sekolah efektif dari teorits ke praktis. Banjarmasin: Rumah Pengetahuan.

Suriansyah, A., \& Aslamiah. (2015). Strategi kepemimpinan kepala sekolah, guru, orang tua dan masyarakat dalam membentuk karakter siswa. Jurnal Cakrawala Pendidikan, 234-247. doi:10.21831/cp.v2i2.4828

Susanto, A. (2016). Manajemen peningkatan kinerja guru: Konsep, strategi, dan implementasi. Jakarta: Prenadamedia Group.

Tim Dosen Administrasi Publik. (2011). Manajemen pendidikan. Yogyakarta: UNY Press.

Yoto. (2011). Model kepemimpinan kepala sekolah pada sekolah menengah kejuruan (sebuah kajian teoritis). Jurnal Teknik Mesin, 17(2). Retrieved from http://journal.um.ac.id/index.php/teknik$\underline{\text { mesin/article/view/3201 }}$

Yulk, \& Gary. (2011). Kepemimpinan dalam organisasi. Yogyakarta: Pustaka Insan Madani. 